\title{
A Brief Note on the Heap Leaching Technologies for the Recovery of Valuable Metals
}

\author{
Thriveni Thenepalli ${ }^{1}\left(\mathbb{D}\right.$, Ramakrishna Chilakala ${ }^{2}$, Lulit Habte ${ }^{3}$, Lai Quang Tuan ${ }^{3,4} \mathbb{D}^{-}$and \\ Chun Sik Kim 1,* \\ 1 Hanil Cement Co, Ltd., 302 Maepo-ri, Maepo-eup, Danyang-gun, Chungcheongbuk-do, Seoul 395-903, \\ Korea; thenepallit@rediffmail.com \\ 2 Department of Bio-based Materials, School of Agriculture and Life Science, Chungnam National University, \\ Daejeon 305-764, Korea; chilakala_ramakrishna@rediffmail.com \\ 3 Department of Resources Recycling, University of Science \& Technology, Daejeon 34113, Korea; \\ luna@kigam.re.kr (L.H.); tuanlai@ust.ac.kr (L.Q.T.) \\ 4 Tectonic and Geomorphology Department, Vietnam Institute of Geoscience and Mineral Resources (VIGMR), \\ Hanoi 151170, Vietnam \\ * Correspondence: sik0117@hanil.com
}

Received: 8 April 2019; Accepted: 10 June 2019; Published: 17 June 2019

check for

\begin{abstract}
Heap leaching is a low-cost technology used in industrial mining to recover precious metals such as gold and uranium, along with several other highly sought after metals like copper, from their primary resources (ores and minerals). For many decades, there has been a growing demand for heap leaching due to its environmental benefits. Heap leaching provides mining operators with a benign, effective and economical solution for the environment and produces only minor emissions from furnaces. The cost of the heap leaching process is low, making this process an attractive option from a financial standpoint. Here, we shall present a brief review of the heap leaching process when applied to the extraction of different metals from primary resources (ores and minerals). This paper presents a roadmap to satisfy future national demands for rare earth elements (REEs). This heap leaching process is applicable for the recovery of REEs from secondary resources such as mining and coal residues. Heap leaching plays a significant role in the recovery of critical elements which are used in clean and green energy applications. In the mining sector, heap leaching is a distinguished method for the recovery of valuable/beneficial metals from low-quality ore. In the present study, we shall report briefly on the heap leaching technologies for valuable metal recovery with economic advantages.
\end{abstract}

Keywords: Heap Leaching; mining waste; recovery; valuable metals; rare earth; energy applications

\section{Introduction}

Heap leaching is one of the oldest and the most traditional mining process used to extract the valuable metals from specific minerals. Basically, this is a hydrometallurgical process in which the solution is applied for the dissolution of minerals from the ore that is used for the extraction of metals. Originally, heap leaching was practiced 500 years ago. Georgius Agricola published a book De Re Metallica in 1557 and reported that the heap leaching process was finished in a 40-day cycle [1]. Since the middle of the $16^{\text {th }}$ century, heap leaching was practiced in Hungary for copper extraction. In 1969, gold heap leaching began in Nevada (birth place of modern heap leaching) and in the middle of the $20^{\text {th }}$ century, the United States Bureau of Mines began applying this technology. Gold and silver heap leaching first began at Cortez in 1969. Currently, 37 different heap leaching operations are active worldwide for the production of gold, which is estimated to be around198 tons per year.

Currently, new heap leaching operations are successfully commissioned throughout the world with the goal of treating mine tailings and residue and to establish effective waste management 
facilities [2,3].In recent years, 50 major heap-leaching, solvent-extraction, electro winning operations have been established throughout the world, and approximately three million tons of copper have been recovered, representing roughly $16 \%$ total copper production [4]. The heap leaching technology developed thus far can be used for different types of ore. Advanced modeling studies and solid fundamentals of heap leaching technology could make the process more adaptable for increasingly composite ores [5].

Several factors are crucial for notable heap leaching operations, such as proper heap building and ore evaluations, efficient comminution methods, and feasible approaches to control the heap leaching process. There have been extensive reports and publications on current heap leach pad designs and construction practices [6]. Current heap leaching methods were developed according to the industrial requirements. For example, heap leach ore depths were increased from 50-60 ft. to $500 \mathrm{ft}$. This function is significant for controlling the economic efficiency, surface area availability and also for reducing the impact of mining reclamation on the environment. Heap leaching solution application rates are optimized for metal recovery with the minimal chemical consumption [7]. The heap leaching process is very simple and thus offers greater economic feasibility over more expensive technologies [8]. The motivation behind the use of heap leaching is financial feasibility.

The major advantage of the heap leaching method over conventional leaching and recovery techniques is that heap leaching consumes less than 0.3 ton of water for one ton of ore. Tank leaching normally operates as a continuous process within specially designed reactors. This approach is also known as a semi-closed system. Essentially, tank leaching is carried out in a set of tanks. In pressure leaching, finely ground ores are chemically treated at high pressures and temperatures within the reactors. The foremost application of the tank leaching method is the extraction of aluminum at low pressures and temperatures [9].The heap leaching process is obviously suitable method and has lot of advantages as mentioned above: however, as per the environmental concern it has some draw backs, such as time consumption, water loss, accidental leakages of pregnant leach solutions, slow heap leach kinetics, and acid mine drainage problems (sulfides).The present objectives of this paper are to provide information on the applications of a unique and versatile heap leaching process for rare earth extraction and to highlight the advantages and limitations of this process.

\section{Heap Leaching of Mines}

Industrial mining processes are the activities involved in the extraction of metals or minerals. A good example can be the classical production process of iron sulfate. In this process, iron pyrite was heaped up and the leachate coming from the heap was collected and boiled with iron resulting in the production of iron sulfate. The basic processes involved in heap leaching are ore crushing, spreading the crushed ore over HDPE or PVC geomembrane-lined pads, and spraying a leaching solvent like sulfuric acid or cyanide over the pads so that valuable minerals will dissolve into the pregnant solution. Metal recovery is then performed through precipitation, smelting or electro-winning and absorption methods.

Generally, low-grade ores of valuable metals like gold, silver, and platinum are mined from the surface of the earth or sometimes subsurface of the earth, pulverized into tiny particles, and collected on to a dense leach pad. The heap leaching process involves several steps. First, a leach solution is used to irrigate the heap. The second step is interaction with the ore particles. Third, the precious metal leaches out of the solution. Fourth, the pregnant solution is collected, and finally, draining of the tailing areas is done for metal extraction. Lime, Portland cement, coal fly ash, and bottom ash, or other materials are mixed with crushed ore for agglomeration. In a few cases, after pulverization, sulfide ores can be treated via chlorination, bio-oxidation, roasting and autoclaving methods prior to the heap leaching process. In gold leaching, two similar types of leaching pads are used to maintain permanent heap operations. A summary of leaching methods used for the extraction of various metals is shown in Table 1. Precious metal recovery by heap leaching [10], base metals from oxide ores [11], Zn [12], and gold recovery by heap bio oxidation. The main concern of this thesis was to understand the gold 
mineralizing process and the optimization of operational parameters during the bio oxidation process. Basically, the low-grade ore was oxidized via the biological heap method, and later it was utilized as a supplementary feed [13]. The heap leaching with computation process is a newly developed heap leaching methodology that combines analytical modeling and the Bernoulli type model to achieve a heap leaching scale up process. This method is very useful to optimize the heap leaching process (design, analysis, control and optimization) and also proposes optimal flow rates for the heap leaching process [14] of gold [15], platinum group metals and base metals [16] sequential heap leaching for platinum group metals [17], heap leaching with mathematical modeling for the extraction of copper was developed [18]. In this paper, the authors reported the heap leaching plan and design for copper leaching by the mathematical model named MINLP and BARON-GAMS solver. They studied different primary variables such as acid price, variable costs, and ore grade quality. These were highly effective on the production capacity of copper.

Table 1. Summary of leaching methods for the extraction of different metals with recovery efficiencies [10-29].

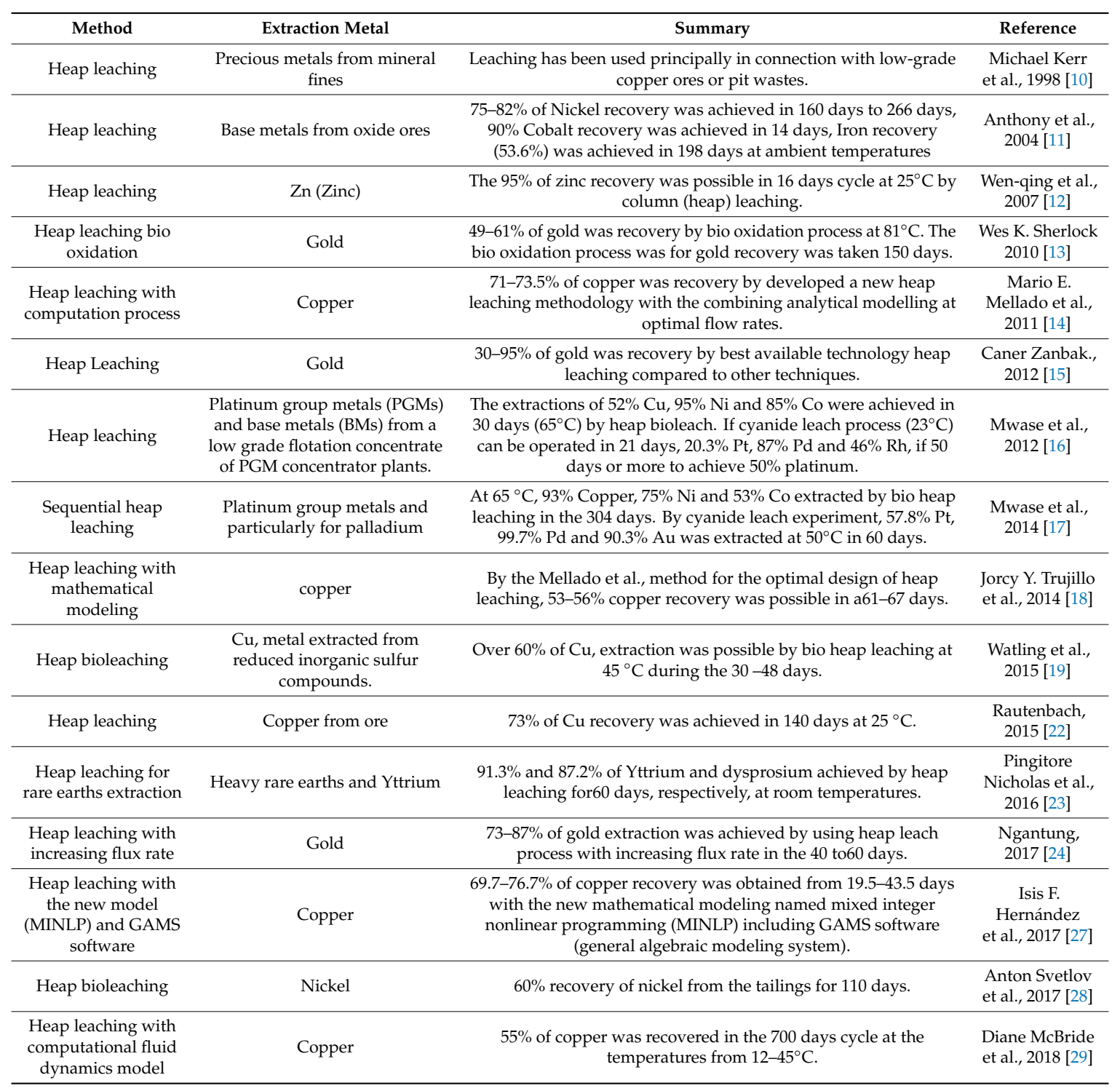


It is possible to recover $60 \%$ of copper through heap bioleaching [19]. The authors discussed an appropriate pad design for high leaching efficiency in the brief reviews $[20,21]$ on the heap pad designing criteria, pad characterization program, pad types, operational kinetics, material handling, and risk assessments. Finally, the authors concluded and recommended some technical tips for successful heap leaching facilities. $\mathrm{Cu}$ recovery of $73 \%$ was achieved in 140 days at $25^{\circ} \mathrm{C}$ [22]. In 60 days, $91.3 \%$ and $87.2 \%$ of Yttrium and dysprosium were achieved by heap leaching, respectively, at room temperatures [23]. The leaching processes with increasing flux rate for the gold recovery were also reported [24]. Some brief reviews reported on the heap leaching of copper and gold [25]. The main objective of this exclusive review paper is to understand the fundamental mechanism of the heap leaching process, as well the theoretical background of different heap leaching processes, global trend of commercial heap leaching operations, challenges, and the innovations and future directions of these process developments. This process is obviously suitable for low grade ores even if it has some draw backs. But it requires some comprehensive engineering concept developments for the higher efficiency of the product by heap leaching. Another brief review paper addressed a key technology for the recovery of valuable metals from low grade ores. The author covered heap leaching benefits, technical draw backs, economic feasibility, leaching kinetics, and environmental concerns [26].

Heap leaching with the new model (MINLP) and GAMS software [27], as well as the new model named mixed integer nonlinear programming (MINLP) including GAMS software (general algebraic modeling system) were utilized for the study of heap design and operational variables for metal recovery. It is one kind of a mathematical modeling applied for the copper leaching system. Recently, a heap bioleaching process was developed in Russia for the recovery of valuable copper and nickel from low-grade ore with a less expensive cost [28]. In Russia, the Murmansk region required urgent research action for the mining wastes. In this region they developed the technology for the recovery of valuable copper and nickel from low-grade ore. During these mining activities, lots of wastes were deposited, so bio heap leaching technology was developed for the recovery of metals from ores with less expensive cost. Heap leaching with the computational fluid dynamics (CFD)model [29] can analyze the heap design, operational parameters, optimization analysis and environmental conditions etc.

In the heap leaching process, initially the ore is pulverized and accumulated before it is placed on the heap in order to increase the mobility of the heap, as well as to maintain a high $\mathrm{pH}$. Agglomeration involves the merging of the pulverized ore with binding material like ash, lime, Portland cement, or other materials. In few cases, pretreatment of sulfide ores by bio-oxidation, autoclaving, roasting, or chlorination before heap leaching. There are two kinds of pad that are used in gold heap leaching, depending on whether the spent ore is removed or not: permanent heap construction on a pad and on-off pads. The former is the one which the leached ore is not removed from the pad and the latter has being where the spent ore is removed, and another fresh ore is allowed to be placed on.

\subsection{Heap Leaching Advantages and Economic factors}

Heap leaching has several advantages and economic benefits. These include low capital requirements and low operating costs [1]; the absence of a milling step for crushing and agglomeration; the simplicity of atmospheric leaching; possible use for the treatment of moderate (medium) grade ores, (pebble size is $\sim 31 \mathrm{~mm}$ with round shape) [30], wastes and few deposits; and omission of liquid-solid separation step for counter-current operations, when metal tensor can do accumulate due to the use of the recycling solution over the heaps. Some ores which require crushing, agglomeration, and conveyor stacking may require little additional cost. The capital expenditures (CAPEX) and operating expenses (OPEX) of copper [31], gold [32], and silver [33] by heap leaching, tank leaching of copper [34], gold [35], and silver [36] and autoclave leaching of copper [37], gold [38], and silver [39] are expressed in million dollars per ton of ore in Table 2. 
Table 2. Comparison of capital expenditures (CAPEX) and operating expenses (OPEX) of copper, gold, and silver by heap leaching, tank leaching and autoclave methods.

\begin{tabular}{ccccccc}
\hline Metal & $\begin{array}{c}\text { Heap } \\
\text { Leaching } \\
\text { Capital } \\
\text { Expenditure } \\
\text { (CAPEX) }\end{array}$ & $\begin{array}{c}\text { Heap } \\
\text { Leaching } \\
\text { Operating } \\
\text { Expenditure } \\
\text { (OPEX) }\end{array}$ & $\begin{array}{c}\text { Tank } \\
\text { Leaching } \\
\text { Capital } \\
\text { Expenditure } \\
\text { (CAPEX) }\end{array}$ & $\begin{array}{c}\text { Tank } \\
\text { Leaching } \\
\text { Operating } \\
\text { Expenditure } \\
\text { (OPEX) }\end{array}$ & $\begin{array}{c}\text { Autoclave } \\
\text { Leaching } \\
\text { Capital } \\
\text { Expenditure } \\
\text { (CAPEX) }\end{array}$ & $\begin{array}{c}\text { Autoclave } \\
\text { Leaching } \\
\text { Operating } \\
\text { ESpenditure } \\
\text { (OPEX) }\end{array}$ \\
\hline Copper & 29.5 & 4.6 & 25 & 66 & 75 & 19 \\
Gore & US $\mathbf{t}$ ore & ore & ore \\
\hline Silver & 22 & 4.51 & 40.9 & 22.28 & 492 & 8.20 \\
\hline
\end{tabular}

\subsection{Heap Leaching of gold and silver}

Heap leaching is a very significant and common process in the copper and gold industry. It is very economical and useful for treating a wide range of low-grade ore bodies on a large scale. The simple heap leaching process is very competitive with other expensive laterite technologies. The Bureau of Mines reported the development of a gold ore heap leaching process which used a diluted cyanide solution for the gold and silver recovery from pregnant effluents by a carbon adsorption-desorption process [40]. Hazardous waste engineering research laboratories submitted a report to the Environmental Protection Agency in the USA describing the great distribution and operational capabilities of the gold/silver heap leaching process and the potential environmental impact and management practices to minimize potential environmental releases [41]. The basic processes involved in heap leaching are crushing the ore, spreading the crushed ore over HDPE or PVC geomembrane-lined pads, spraying leaching solvent like sulphuric acid or cyanide over the pads and then valuable minerals will dissolve into the pregnant solution. Metal recovery is then performed through precipitation, smelting or electro-winning and absorption methods [42]. Figure 1 shows a flow chart of a gold heap leach operation [43]. A hydrometallurgical process has been designed for the amenable gold heap leaching from low-grade gold ore [44,45].

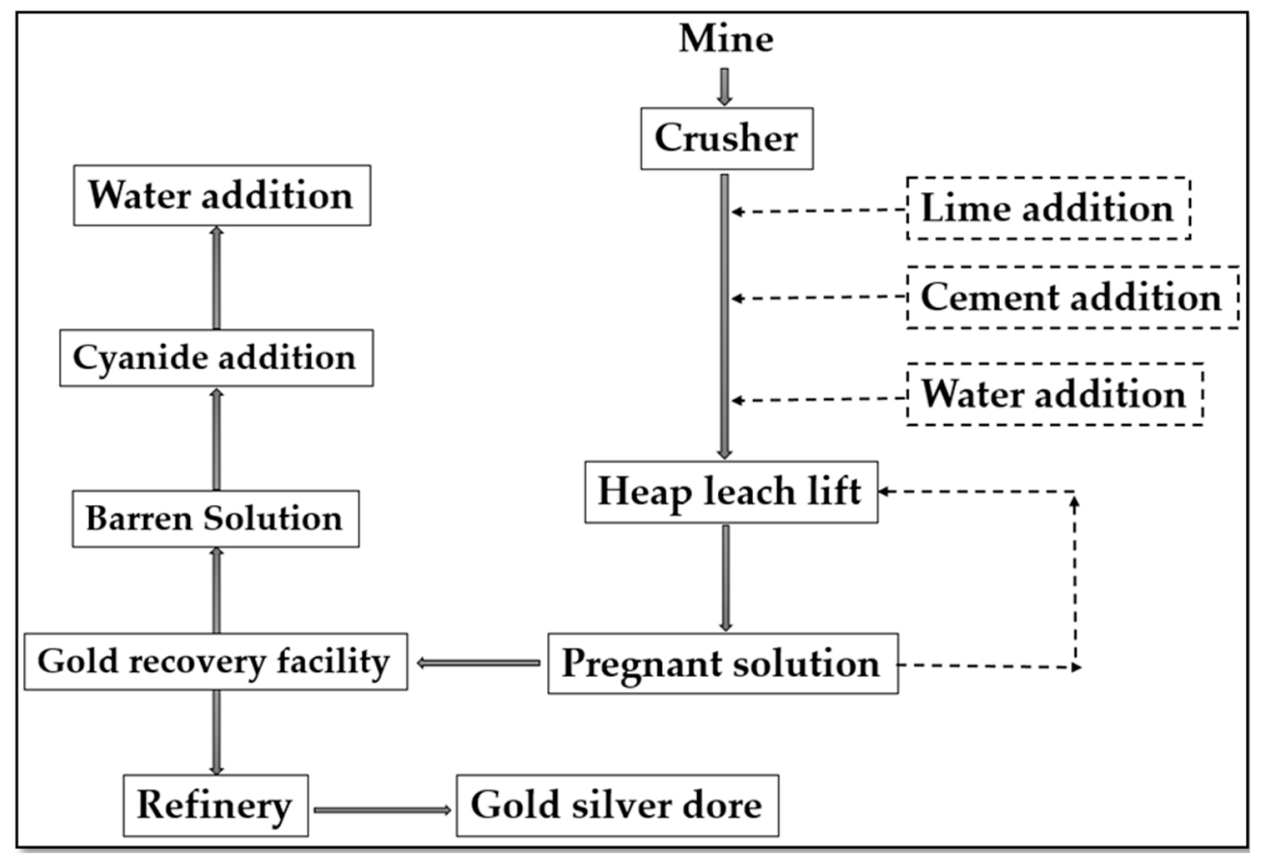

Figure 1. Chart of a gold heap-leach operation (adopted and modified from the reference 43). 


\subsection{Heap Leaching of Copper}

There are numerous reports available on copper heap leaching from copper ore [46,47]. Some researchers have used heap leaching technology for the recovery of copper by using sodium nitrate as an oxidizing agent. The $\mathrm{pH}$ of the heap was maintained at $\mathrm{pH}<1.7$ [48]. Other investigations reported the heap leaching process of copper from diesel deposits [49]. The non-ionic surfactant EVD61549 (a wetting agent) was used to increase the copper heap leaching efficiency [50]. Heap leaching of waste copper ores from Volkovskoe deposits has also been considered for sulphuric acid leaching ( $25-75 \mathrm{~kg} / \mathrm{t}$ ore). Over a period of three months, the copper leaching efficiency reached $76-78 \%$ overall. The copper recovery efficiency increased with an increase in the leaching time [51].

\subsection{Heap Leaching of Uranium}

Large-scale uranium heap leaching activities have operated since the 1970s and 1980s. Historically, sources of uranium ore contain $\geq 0.05 \%$ of uranium/thorium. In the 1950s and 1960s, ores containing less than $0.05 \%$ uranium were periodically refined in small heaps. There are three methods used for uranium recovery, namely: traditional milling, in situ recovery (ISR), and heap leaching methods. In the USA, heap leaching technology is widely used for the recovery of uranium. A rancher exploration and development corporation in Colorado was operated between 1977 and 1979 [52]. Some investigations reported bacterial leaching processes. Generally, problems arose during the oxidation of $\mathrm{U}^{+4}$ species, and approximately $70 \%$ could be recovered. Heap leaching technologies eliminate grinding, tank leaching and the solid/liquid separation step, and it is likely applicable to many types of low-grade uranium ore of many types. The conventional leach times are between one and six months. Recently, researchers reported the analytical models for the heap leaching by global sensitivity analysis and uncertainty analysis [53]. Figure 2 shows a flow diagram of gold, copper and uranium heap leach operation flow sheets [54].

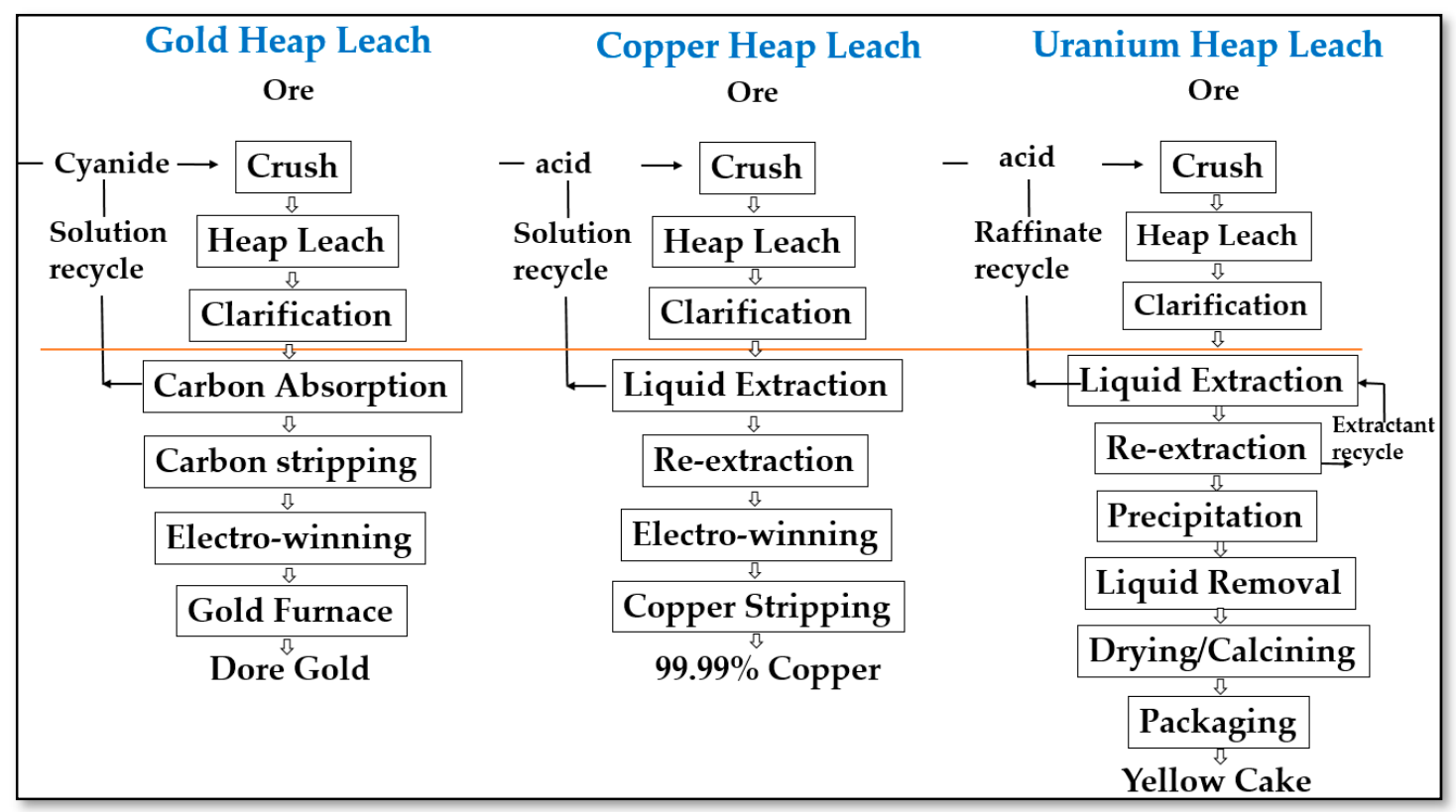

Figure 2. Flow diagrams of heap leaching processes of gold, copper, and uranium (adopted and modified from reference 54).

\section{Rare Earth Elements Recovery by Heap Leaching}

Recently, rare earth appliances are significantly increased for new products. During the past 20 years, REEs have many new applications such as clean energy, petroleum refining, electronics, and automobiles. Military applications have also arisen as these materials are widely used in 
communication systems, avionics, lasers, precision-guided munitions, radar systems, satellites and night vision equipment (Figure 3).

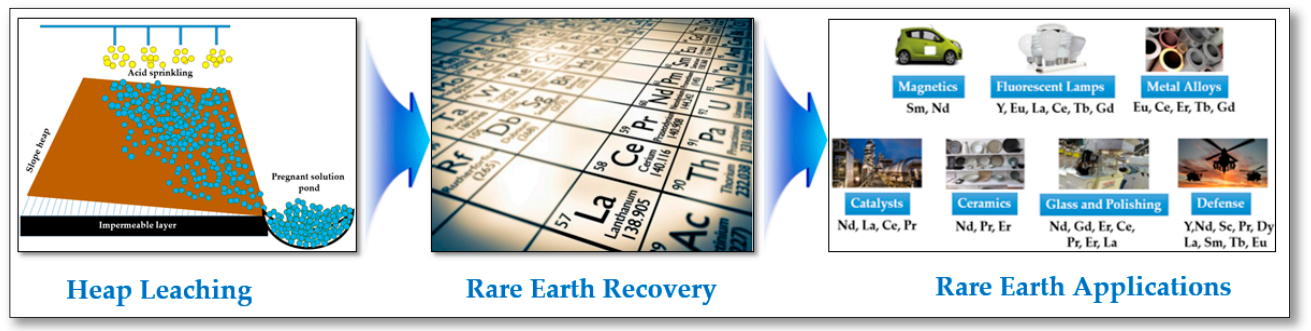

Figure 3. Heap leaching for rare earth recovery.

The assessment and source of REEs are in much interest, and advanced technologies are therefore required for the recovery of critical rare earths from waste residue via the heap leaching process. In the second generation of leaching technology, heap leaching with $(\mathrm{NH} 4)_{2} \mathrm{SO}_{4}$ in the early 1980 s was used to enhance the product purity to more than $92 \%$ for the total rare earth oxide content. During the washing process, the solid-to-liquid ratio was maintained at approximately 0.6:1 build upon the leaching time and heap size. Leaching times ranging from 100 to $320 \mathrm{~h}$ are more beneficial for rare earth extraction, with rates up to $90 \%$ realized [55].

Ion-adsorption clays from various origins or ores are rich sources of rare earths and the recovery process by in-situ leaching [56,57] and heap leaching [58]. 80\% of the rare earths such as $\mathrm{Y}, \mathrm{Nd}$, $\mathrm{Eu}, \mathrm{Tb}$, and Dy were recovered by several process including physical separation, bio oxidation, heap leaching, precipitation and solvent extraction respectively. In 250 days, $85 \%$ of there're earths were leached with $\mathrm{pH} 0$. When $\mathrm{pH}$ was increased to 3 , rare earth recovery was observed to increase by two-fold. Texas rare earth resources independently confirmed a 79.9\% recovery rate by the heap leaching process [59]. Recently, heap leaching was applied for the recovery of the yttrium, from the ore yttrofluorite. Yttrium-bearing fluorite at Round Top Mountain is a rich source of Yttrium, and other heavy rare earth elements were recovered by the heap leaching process. In 60 days, $91.3 \%$ and $87.2 \%$ of Yttrium and dysprosium were achieved by heap leaching, respectively, at room temperatures [23].

Recently, the National Energy Technology Laboratory (NETL) funded the University of Utah and Virginia Technology for the extraction of rare earths from coal refuse by heap leaching, along with other sequential processes such as coal processing, bio oxidation, solution treatment, solvent extraction, and precipitation technologies respectively [60].

\section{Conclusions}

Heap leaching technologies have been profitably adopted for the recovery of highly sought after metals. Worldwide, a huge interest in heap leaching projects has-been observed for the recovery of precious metals. Heap leaching is an essential metallurgical process which has demonstrated a strong potential to reduce costs and liberate metals from challenging deposits. Nowadays, prices for all precious metals and rare earths are increasing rapidly due to the continuous demand in green technology applications. Heap leaching is a more economic process than any other conventional method, and exceptionally so for the recovery of precious metals from low grade ore.

Author Contributions: T.T., R.C., L.H., and L.Q.T collected the information, summarized and wrote the manuscript. C.H.K. corrected the final manuscript and agreed to submit this data to the sustainability journal.

Funding: This study was supported by the Energy Technology Development Project [20141010101880] of the Korea Institute of Energy Technology Evaluation and Planning, financed by the Ministry of Trade, Industry, and Energy.

Conflicts of Interest: The authors declare no conflict of interest. 


\section{References}

1. Kappes, D.W. Precious metal heap leach design and practice. In Mineral Processing Plant Design, Practice, and Control; Mular, A.L., Haibe, D.N., Barrett, D.J., Eds.; Society for Mining, Metallurgy, and Exploration: Denver, CO, USA, 2002; Volume 2, pp. 1606-1630. ISBN 0-87335-223-8.

2. Terry, M.; David, P. Experience-based approach to successful heap leach pad design. Min. World 2015, 12, 28-35.

3. Caner, Z. Heap leaching technique in mining, within the context of best available techniques (BAT), Report. Euromines 2013, 1-33. Available online: http://www.euromines.org/files/mining-europe/mining-techniques/ batforheapleaching-feb2013-c.zanbak-euromines.pdf (accessed on 6 June 2019).

4. Basov, V. Heap Leach: Mining Breakthrough Technology. Min. Com News 2015, 1-4. Available online: http://www.mining.com/heap-leach-minings-breakthrough-technology/ (accessed on 6 June 2019).

5. John, C. Small but mighty. Int. Min. 2012, 26-65. Available online: https://im-mining.com/ (accessed on 10 June 2019).

6. Breitenbach, A.J. Overview study of several geomembrane liner failures under high fill load conditions. In Geosynthetics'97 Conference Proceedings; Industrial Fabrics Association International: Long Beach, CA, USA, 1997; pp. 1045-1062.

7. Senninger Mining Solutions. Heap Leaching Guide. 2012, pp. 1-6. Available online: http://www.synsamm. co.za/wp-content/uploads/2018/09/Heap-Leaching-Brochure-English.pdf (accessed on 6 June 2019).

8. Bartlett, R.W. Metal extraction from ores by heap leaching. Met. Mater. Trans. B 1997, 28, 529-545. [CrossRef]

9. John, L.U. Pressure leaching coming of age or has it been here for along time? Rpm Glob. Perspect. 2015, 130, 1-3.

10. Michael Kerr, E.; Aurora, I. Polymeric Combinations Used as Copper and Precious Metal Heap Leaching Agglomeration Aids. U.S.Patent 5,833,937, 10 November 1998.

11. Anthony, S.; Purkiss, R. Heap Leaching Base Metals from Oxide Ores. Patent WO2004031422A1, 10 January 2004.

12. Qin, W.Q.; Li, W.Z.; Lan, Z.Y.; Qiu, G.Z. Simulated small-scale pilot plant heap leaching of low-grade oxide zinc ore with integrated selective extraction of zinc. Miner. Eng. 2007, 20, 694-700. [CrossRef]

13. Sherlock, W.K. Issues affecting heap biooxidation of low-grade refractory gold ore:formation of secondary sulfates, ore lithology, alteration and sulfide mineralogy at gold quarry, Carlin, Nevada. Master's Thesis, University of Nevada, Reno, Reno, NA, USA, June 2010.

14. Mellado, M.E.; Gálvez, E.D.; Cisternas, L.A. On the optimization off low rates on copper heap leaching operations. Int. J. Min. Proc. 2011, 101, 75-80. [CrossRef]

15. Zanbak, C. Heap leaching technique in mining with in the context of best available techniques (BAT) - Introductory Statement by Euromines. Technol. Rep. 2012, 1-33. [CrossRef]

16. Mwase, J.M.; Petersen, J.; Eksteen, J.J. A conceptual flow sheet for heap leaching of platinum group metals (PGMs) from a low-grade ore concentrate. Hydrometallurgy 2012, 111-112, 129-135. [CrossRef]

17. Mwase, J.M.; Petersen, J.; Eksteen, J.J. A novel sequential heap leach process for treating crushed Plat reef ore. Hydrometallurgy 2014, 141, 97-104. [CrossRef]

18. Trujilloc, J.Y.; Cisternas, L.A.; Gálveza, E.D.; Mellado, M.E. Optimal design and planning of heap leaching process. Application to copper oxide leaching. Chem. Eng. Res. Des. 2014, 92, 308-317. [CrossRef]

19. Watling, H.R.; Shiers, D.W.; Collinson, D.M. Extremophiles in mineral sulphide heaps: Some bacterial responses to variable temperature, acidity and solution composition. Microorganisms 2015, 3, 364-390. [CrossRef] [PubMed]

20. Panda, S.; Akcil, A.; Pradhan, N.; Deveci, H. Current scenario of chalcopyrite bioleaching: A review on the recent advances to its heap-leach technology. Bioresour. Technol. 2015, 196, 694-706. [CrossRef] [PubMed]

21. Pradhan, N.; Nathsarma, K.C.; Srinivasa Rao, K.; Behari Sukla, L. Heap bioleaching of chalcopyrite: A review. Min. Eng. 2008, 21, 355-365. [CrossRef]

22. Rautenbach, G.F. Heap Leaching of Copper. Patent WO2015059551A1, 30 April 2015.

23. Pingitore, N.E. Extraction and Recovery of Yttrium and Rare Earth Elements. U.S. Patent US20160138133A1, 19 May 2016.

24. Ngantung, B.; Agustin, R. Increasing flux rate to shorten leaching period and ramp-up production. Am. Inst. Phys. (Aip) Conf. Proc. 2017, 1805, 030009. [CrossRef] 
25. Ghorbani, Y.; Franzidis, J.P.; Petersen, J. Heap leaching technology-current state, innovations, and future directions: A review. Min. Proc. Ext. Met. Rev. 2016, 37, 73-119. [CrossRef]

26. Petersen, J. Heap leaching as a key technology for recovery of values from low-grade ores-A brief overview. Hydrometallurgy 2016, 165, 206-212. [CrossRef]

27. Hernández, I.F.; Ordóñez, J.I.; Robles, P.A.; Gálvez, E.D.; Cisternas, L.A. A methodology for design and operation of heap leaching systems. Miner. Process. Extr. Metall. Rev. 2017, 38, 180-192. [CrossRef]

28. Svetlov, A.; Seleznev, S.; Makarov, D.; Selivanova, E.; Masloboev, V.; Nesterov, D. Heap leaching and perspectives of bioleaching technology for the processing of low-grade copper-nickel sulfide ores in Murmansk Region, Russia. J. Pol. Min. Eng. Soc. (Inz. Miner.) 2017, 39, 51-59. [CrossRef]

29. McBride, D.; Gebhardt, J.; Croft, N.; Cross, M. Heap Leaching: Modelling and forecasting using CFD technology. Minerals 2018, 8, 9. [CrossRef]

30. Tetteh, G.M.; Lartey, E.O. Texture and Gold grade as guides to blending of conglomerate ore. Int. J. Sci. Technol. Res. 2018, 7, 61-66.

31. Brown, P. Alous Copper-Silver mine project scoping study; D114506/R17712; Odyssey Resources Ltd.: Longueuil, QC, Canada, 2007; pp. 1-68.

32. Sulliden. Clear Path to Production for Shahuindo: A Low Cost Heap Leach Gold Project in Peru; Resource investing in Latin America and Canada; Ministry of Mines and Energy, Peru and National Society of Mining, Oil, \& Energy: Lima, Peru, 2013; pp. 1-51.

33. Star Gold Inc. Scoping Study, Longstreet Gold Project, Nye County, NV, USA; A-Z Mining Professionals Limited: Thunder Bay, ON, Canada, 2014; pp. 1-110.

34. Crundwell, F. Process and Economic Considerations in Copper Metallurgy; CMS olutions Pvt.Ltd.: Corinth, Greece, 2006; pp. 1-53.

35. Stange, W. The process design of gold leaching and carbon-in-pulp circuits. J. South Afr. Inst. Min. Metall. 1999, 13-26. Available online: https://www.saimm.co.za/Journal/v099n01p013.pdf (accessed on 6 June 2019).

36. Mcewen Mining Inc. Preliminary Economic Assessment for the Fenix Project at Mcewen Mining Inc.'s Operations in Sinaloa, Mexico; Mcewen Mining Inc.: Belmont, Australia, 2018; pp. 1-330.

37. Barr, G.; Defreyne, J.; Mayhew, K. CESLcopper process-An Economic Alternative to Smelting. CESL Engineering. 2005, pp. 1-13. Available online: https://www.teck.com/media/CESL-PublicationCopper-Process-Intermin-2005.pdf (accessed on 6 June 2019).

38. Fleming, C.A. Platsoltm Process Provides a Viable Alternative to Smelting; SGS Minerals Services, Technical paper 2002-01; SGS A.G.: Geneva, Switzerland, 2002; pp. 1-5.

39. Anderson, C.G. The optimization, design and economics of industrial NSC oxidative pressure leaching of complex sulfide concentrates. Int. J. Eng. Sci. 2013, 2, 1-16.

40. Heinen, H.J.; Peterson, D.G.; Lindstrom, R.E. Processing Gold Ores Using Heap Leach Carbon Adsorption Methods; IC8770; U.S. Department of the Interior, Bureauof Mines: Reno, NV, USA, 1978; pp. 1-21.

41. Hoye, R. Gold/Silver Heap Leaching and Management Practices that Minimize the Potential for Cyanide Releases; EPA/600/2-88/002; Final Report; U.S. Environmental Protection Agency: Washington, DC, USA, 1987; pp. 1-113.

42. Technical Note, Mining Heap Leach Pads and Tailings Dams, Solmax International Technical Notes. Available online: https://www.solmax.com/en (accessed on 6 June 2019).

43. Donald, I.B. Estimated Water Requirements for Gold Heap-Leach Operations. (ver.1.1,11 December2012): U.S. Geological Survey Open-File Report 2012-1085. pp. 1-17. Available online: http://pubs.usgs.gov/of/2012/1085 (accessed on 6 June 2019).

44. John, O.M.; House, C.I. The Chemistry of Gold Extraction; Society for Mining Metallurgy, and Exploration Inc.: Littleton, CO, USA, 2006.

45. Leong Eugene, W.W.; Mujumdar, A.S. Gold Extraction and Recovery Processes; The National University of Singapore: Singapore, 2010; pp. 1-20.

46. Padilla, G.A.; Cisternas, L.A.; Cueto, J.Y. On the optimization of heap leaching. Miner. Eng. 2008, 21, 673-678. [CrossRef]

47. Ilankoon, I.M.S.K.; Neethling, S.J. The effect of particle porosity on liquid hold up in heap leaching. Miner. Eng. 2013, 45, 73-80. [CrossRef]

48. Arias, J.A. Heap Leaching Copper ore Using Sodium Nitrate. U.S. Patent US6,569,391B1, 27 May 2003. 
49. Mbuyu, L.; Kasonde, M.; Kitala, K.; Lwambiyi, N.M.; Mukulu, D. Investigation in to the heap leaching of copper ore from the disele deposit. Hydrometallurgy 2009, 98, 177-180. [CrossRef]

50. Matthias, V.; Andreas, L.; Bernd, F.; Hans-Peter, S.E. Improvements in copper heap leaching by use of wetting agents. Proc. EMC 2009, 1-12. [CrossRef]

51. Tomina, V.N.; Khrennikov, A.A.; Lebed, A.B.; Naboichenko, S.S. Heap leaching of copper from the ores of Volkovskoe deposit. Russ. J. Non-Ferrous Met 2010, 51, 263-267. [CrossRef]

52. Kimberly, M.; Frank, F. Conventional Heap Leaching of Uranium ore in the Western United States. Available online: https://www.korsika-traumurlaub.de/2017-Nov/heap-leaching-uranium.html;www.infomine.com. (accessed on 6 June 2019).

53. Mario, E.M.; Freddy, A.L.; Luis, A.C.; Edelmira, D.G.; Felipe, D.S. A posteriori analysis of analytical models for heap leaching using uncertainty and global sensitivity analyses. Minerals 2018, 8, 44. [CrossRef]

54. Henry, S. International Atomic Energy Agency, Building uranium heap leach project. In Proceedings of the URAM Conference, Vienna, Austria, 23-27 June 2014; pp. 1-38.

55. Vladimiros, G.P.; Georgiana, M. Recovery of rare earth elements from clay minerals. In Proceedings of the ERES 2014: 1st European Rare Earth Resources Conference, Milos Island, Greece, 4-7 April 2014; pp. 1-12.

56. Chi, R.; Zhang, Z.; Xu, Z.; He, Z.; Ruan, Y. Novel solution injection technology for in-situ leaching of weathered crust elution-deposited rare earth ores. In Proceedings of the 53rd Conference of Metallurgists (COM2014), Metallurgical Society of the Canadian Institute of Mining, Metallurgy and Petroleum (MetSoc-CIM), Vancouver, BC, Canada, 28 September-1 October 2014.

57. Vahidi, E.; Navarroc, J.; Zhao, F. An initial life cycle assessment of rare earth oxides production from ion-adsorption clays. Resour. Conserv. Recycl. 2016, 113, 1-11. [CrossRef]

58. Rick, Q.H.; Wencai, Z.; Xinbo, Y.; Mohammad, R. Concept ion of an integrated flow sheet for rare earth elements recovery from coal coarse refuse. Miner. Eng. 2018, 122, 233-240. [CrossRef]

59. Sierra, B. Impressive Heavy rare Earth Recoveries Increase Confidence in Heap Leach Processing Option; Texas Rare Earth Resources Corp.: Sierra Blanca, TX, USA, 2013.

60. Free, M.; Sarswat, P.; Luttrell, G.; Noble, A.; Hu, X.; Allen, L.; McNeill, M.; Kim, D.J.; Arce, I. Economic extraction, recovery, and upgrading of rare earth elements from coal-based resources. In Proceedings of the 2018 AIChE Annual Meeting, Pittsburgh, PA, USA, 1 November 2018. 